\title{
НАУКОВЕ ЗАБЕЗПЕЧЕННЯ РОЗВИТКУ ОСВІТИ ДОРОСЛИХ В УКРӒ̈НІ
}

\author{
Наукова доповідь на загальних зборах НАПН України 20 листопада 2020 р.
} https://doi.org/10.37472/2707-305X-2020-2-2-1-1

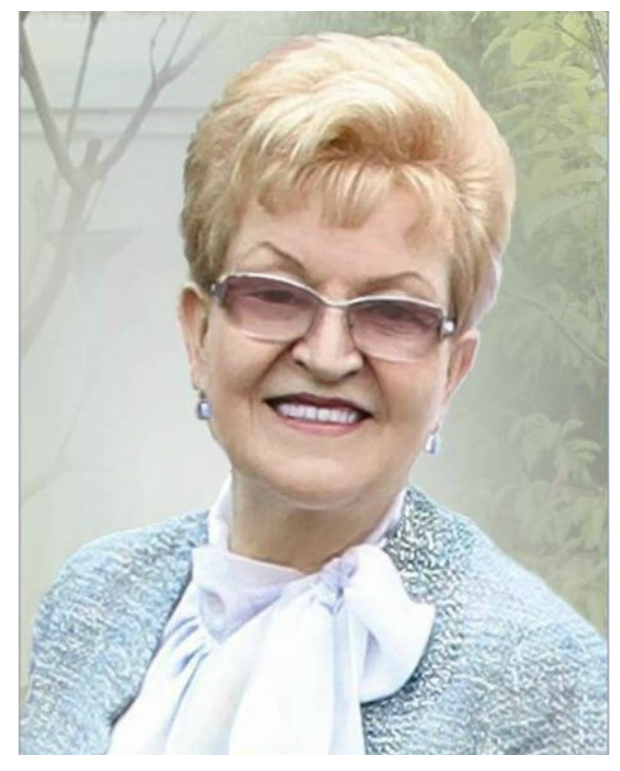

\section{НИЧКАЛО Нелля Григорівна}

доктор педагогічних наук, профессор, дійсний член (академік) НАПН України, академік-секретар Відділення професійної освіти і освіти дорослих Національної академії педагогічних наук України, м. Київ, Україна

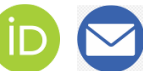

Анотачія. Висвітлено проблеми наукового забезпечення розвитку освіти дорослих в Україні в умовах глобалізаційних та євроінтеграчійних процесів і переходу до цифрового суспільства. Здійснено порівняльний аналіз зарубіжного і вітчизняного досвіду реалізації державної освітньої політики з цього напряму. Особливу увагу приділено науковому забезпеченню розвитку освіти дорослих у діяльності НАПН України. Привернуто увагу до цінного досвіду просвітницької діяльності серед різних категорій дорослого населення у різних регіонах України, психологічної реабілітації постраждалих в зоні проведення антитерористичної операції у Донещькій і Луганській областях. Обгрунтовано пропозищії щодо подальших інновачійних пошуків з проблем неперервної освіти освіти впродовж життя.

Ключові слова: освіта дорослих; формальна, неформальна та інформальна форма освіти дорослих; наукове забезпечення; андрагог; педагогізація.

На початку XXI століття освіта дорослого населення набуває винятково важливого значення. Соціально-економічний, культурний і технологічний прогрес потребує від фахівців різних галузей неперервного оновлення знань, розвитку вмінь та оволодіння новими компетентностями. Реалізації цих вимог покликана сприяти державна політика щодо розвитку людського капіталу, освіти дорослого населення й готовність суспільства до кардинальних змін у цій сфері.

Проблема наукового забезпечення розвитку освіти дорослих $\epsilon$ міждисциплінарною, багатоаспектною, її розв'язання у сучасних умовах і в перспективі залежить від сукупності зовнішніх і внутрішніх чинників. 3 урахуванням цього висвітлено в доповіді Відділення професійної освіти і освіти дорослих НАПН України такі основні аспекти:

1. Зарубіжний досвід освіти дорослих.

2. Стан освіти дорослих у сучасній Україні.

3. Наукове забезпечення розвитку освіти дорослих у діяльності НАПН України.

4. Актуальні проблеми у розвитку освіти дорослих та науково обґрунтовані пропозиції щодо їх розв'язання.

Глобалізаційні та євроінтеграційні процеси, нові виклики, суперечності і загрози в умовах переходу до цифрового суспільства зумовлюють необхідність якісних змін в організації освіти дорослих як невід'ємної складової освіти впродовж життя. Підтвердженням цієї тези є індикатори розвитку людського капіталу, серед яких провідною стає участь дорослих у неперервній освіті. За результатами міжнародних досліджень, у країнах - членах ОЕСР в середньому $40 \%$ дорослих беруть участь у програмах освіти дорослих, тоді як в Україні лише 9\% дорослих охоплено 
різними видами навчання (Мінекономрозвитку України, 2017).

Значну увагу цим питанням приділено у документах міжнародних організацій, зокрема в таких: Белемські рамки дій: «Життя і навчання впродовж життя для успішного майбутнього сила навчання дорослих» («Belém Framework for Action: harnessing the power and potential of adult learning and education for a viable future», 2010), Інчхонська декларація «Освіта 2030: на шляху до інклюзивної та справедливої якісної освіти та навчання впродовж життя» («Education 2030. Incheon Declaration: Towards Inclusive an Equitable Quality Education and Lifelong Learning for All», 2015), Рекомендації щодо навчання та освіти дорослих («Recommendation on Adult Learning and Education», 2016), Глобальний звіт стосовно навчання та освіти дорослих «Не залишити нікого позаду: участь, рівність, інклюзія» (4th Global Report on Adult Learning and Education «Leave No One Behind: Participation, Equity and Inclusion», 2019), «Отримання необхідних навичок: готовність системи освіти дорослих до майбутнього» («Getting Skills Right: Future-Ready Adult Learning Systems», 2019).

\section{Зарубіжний досвід освіти дорослих}

Звернення до аналітичного документа «Education at a Glance» («Освіта 3 погляду») Організації економічного співробітництва та розвитку (вересень 2020 р.) дає змогу виокремити основні світові тенденції розвитку освіти дорослих (OECD, 2020, с. 136-148).

Найбільш поширеними є програми неформального навчання, пов'язані із розвитком професійної компетентності та оплачувані роботодавцями (44\% респондентів хоча б один раз брали участь у такій програмі протягом року; натомість лише 9\% - у програмах, не пов'язаних із підвищенням рівня їхньої професійної компетентності) (рис. 1).

Великі компанії (із кількістю зайнятих більше 259 осіб) пропонують своїм працівникам систематичне підвищення професійної компетентності (витрачаючи на таке навчання 2,1\% від загальних витрат на персонал, у той час як малі підприємства (10-49 зайнятих) витрачають в середньому лише 1,3\%) (рис. 2).

Кореляція між частотою участі дорослої особи у програмах навчання та початковим рівнем ії освіти є такою: 62\% осіб із вищою освітою брали участь у програмах формального та неформального навчання, і лише $24 \%$ осіб із середньою освітою були учасниками як мінімум однієї програми впродовж року. Мотивами до участі у дорослих у таких програмах є: практична корисність отриманих знань (покращення власних перспектив щодо працевлаштування, набуття актуальних для XXI століття навичок, підвищення власної ефективності) та інтелектуальні мотиви (потреба в постійному інтелектуальному розвитку, задоволення від отримання нових знань із суміжних областей).

Доросле населення частіше бере участь у програмах неформального навчання (у порівнянні 3 програмами формального навчання). В середньому, час на одну програму формального навчання становить 406 годин, у той час як на одну програму неформального навчання - лише 73 години.

Ключові ідеї цього документа такі:

- у майбутньому саме доросле населення становитиме левову частку зайнятих, що вимагає безперервного підвищення їхньої професійної компетентності;

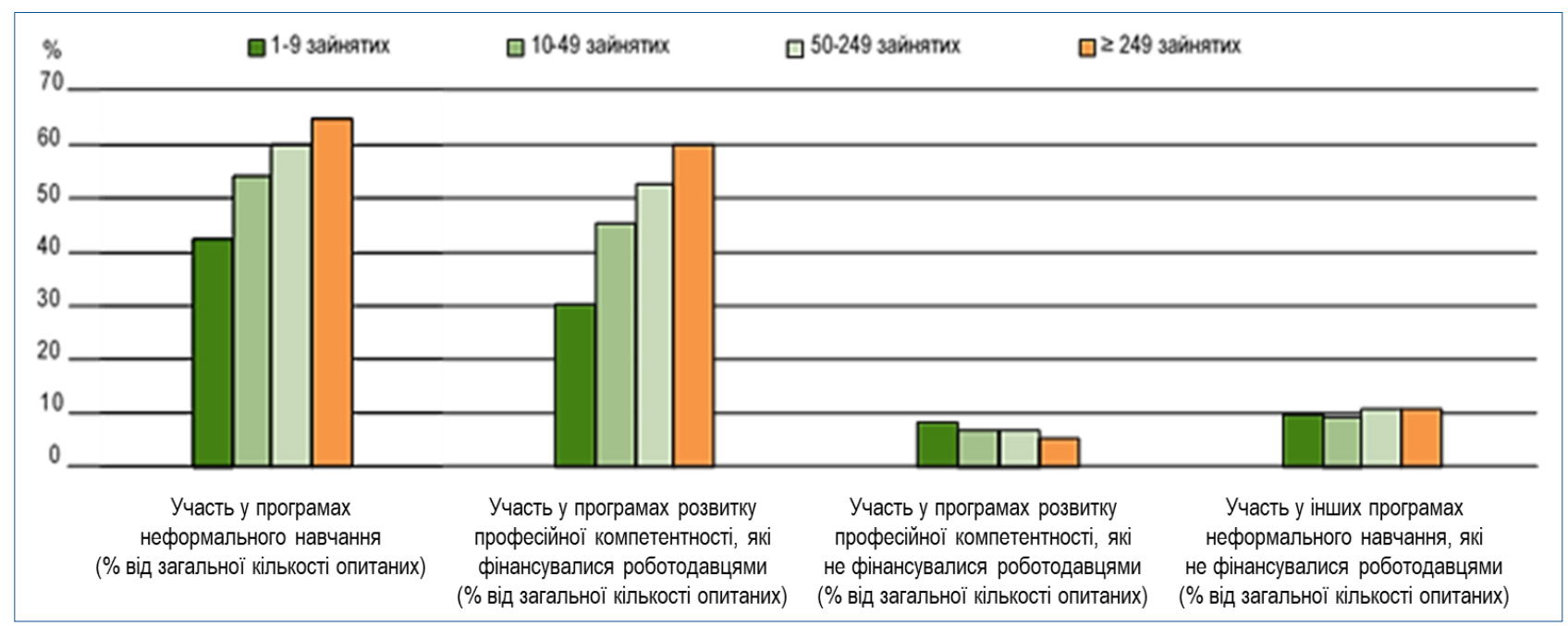

Рис. 1. Частка зайнятих осіб віком від 25 до 64 років, які брали участь у програмах неформального навчання 


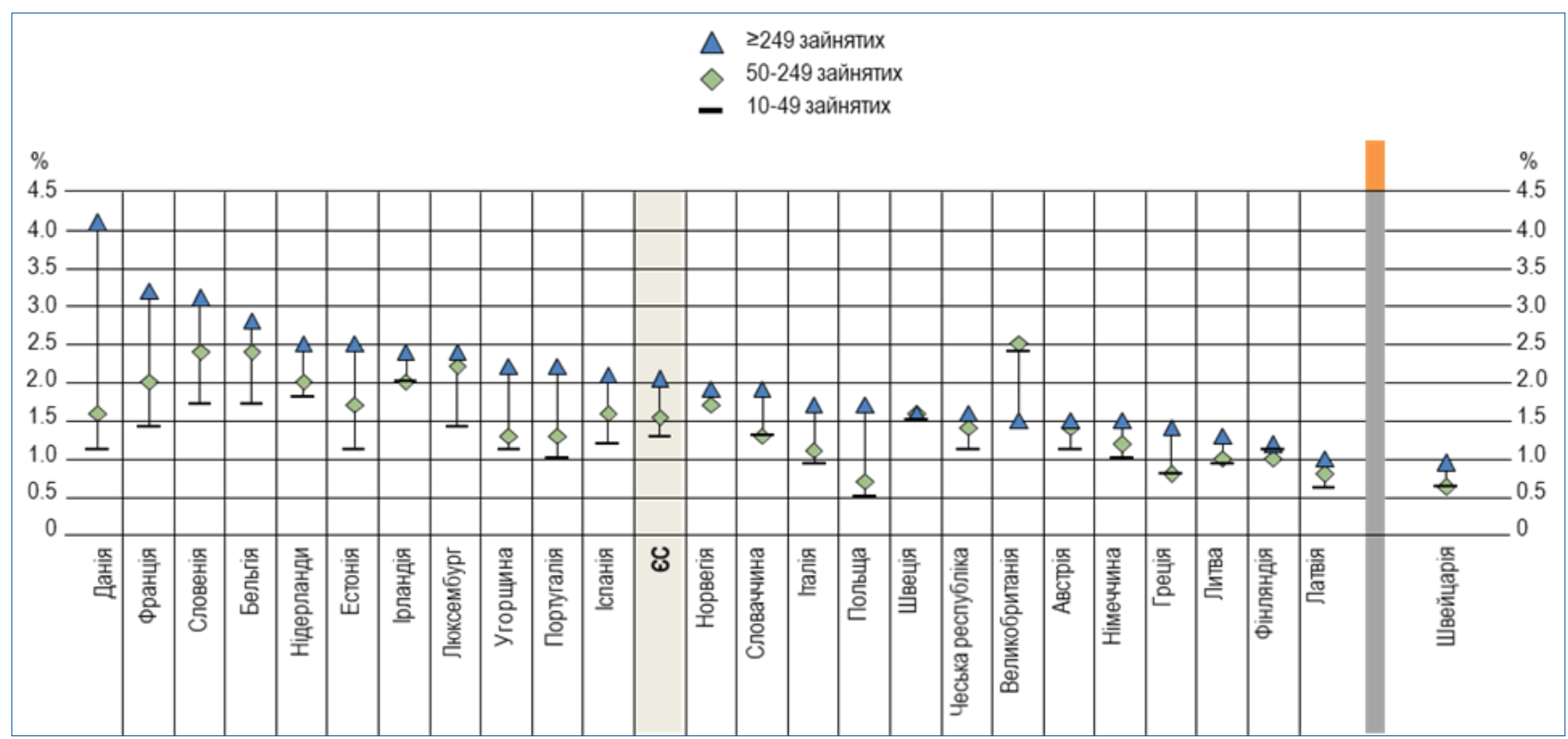

Рис. 2. Витрати на навчання персоналу (\% від загальної кількості витрат на персонал)

- освіта дорослих покликана сприяти досягненню економічних цілей й визначати напрями персонального розвитку, сприяти збереженню здоров'я, громадянському вихованню та соціальній інклюзії;

- найбільшу потребу доросле населення відчуває у програмах розвитку цифрових компетентностей, технологій інтерактивної взаємодії (зокрема, дистанційної) роботи, зокрема дорослі учні з особливими потребами. Водночас виявлено зростання частоти використання цифрових технологій у освітньому процесі;

- COVID-19 спричинив суттєві зміни у звичному способі життя та зумовив посилене бажання працівників виконувати свої обов'язки дистанційно, що, у свою чергу, вимагає додаткових навичок, адаптивності та гнучкості (OECD, 2020).

З 1968 р. у структурі Організації економічного співробітництва та розвитку функціонує Центр освітніх досліджень і інновацій. У статистичному освітньому щорічнику за 2018 р. значну увагу приділено освіті дорослих. За глосарієм ОЕСР, дорослими вважаються особи віком 25-64 років (переважно з огляду на типовий вік придатності для ринку праці), їх навчання в основному здійснюється за програмами формальної та неформальної освіти. За даними цієї організації, у середньому, 21,6\% дорослих мають освіту, нижчу за повну середню, 43,2\% - повну середню освіту, $35,7 \%$ - вищу освіту. Тобто роль формальної освіти для підвищення освітнього рівня дорослих далеко не вичерпана, хоча вона $є$ актуальною для відносно молодого віку (до 40 років). Лише 1\% осіб вікової групи «40 і більше років» у цих краї- нах бере участь у формальній освіті. 40 років вважається пограничним віком, після якого формальна освіта перестає бути провідною для дорослих. У країнах ОЕСР різними є підходи до неформальної освіти, зокрема, до фінансування програм підготовки. У сучасних умовах постає проблема обґрунтування концептуальних засад простору освіти дорослих в єдності його формальної, неформальної та інформальної складових (освіти, підготовки) (Луговий \& Таланова, 2018).

Зарубіжний досвід переконливо свідчить, що успішному розвитку освіти дорослих сприяють передусім державна політика й законодавча база, що передбачають відповідальність держави, підприємців, територіальних громад і громадських організацій за підтримку професійного і особистісного розвитку громадян, визначають порядок фінансування цієї діяльності, атестаційні вимоги. У багатьох країнах (США, Франції, Канаді, Швеції, Японії, Іспанії та інших) реалізуються державні програми, спрямовані на розвиток освіти різних категорій дорослого населення. Прийнято законодавчі акти, якими визначено шляхи розвитку, джерела фінансування і підтримки освіти дорослих тощо. Так, у Норвегії «Акт про освіту дорослих» набув чинності ще у 1976 р., у Німеччині також вже давно діють відповідні земельні закони.

Законодавство зарубіжних країн у сфері освіти дорослих є потужним і розгалуженим. Наприклад, у Фінляндії прийнято п'ять законів, що регулюють освіту дорослих. 31998 р. тут діють Закон і Указ про професійне навчання дорослих та Закон і Указ про добровільну просвітницьку 
діяльність. У 2000 р. набув чинності Закон про матеріальну підтримку в системі навчання дорослих, а у 2010-2011 рр. прийнято Закон про неформальну освіту дорослих. 32003 р. успішно діють Закон й Указ «Про професійну підготовку вчителів для дорослих». У Данії також прийнято законодавчі акти, якими регулюється розвиток освіти дорослих. Ще у 1985 р. набув чинності один із перших законів - «Закон про освіту працівників», що регулює освіту дорослих у цій країні. Поряд із цим, чинними є Закони Данії «Про освіту для дорослих іммігрантів», «Про спеціальну освіту для дорослих», «Про оплачувану відпустку для навчання», «Про освіту для дорослих та подальше навчання». Декілька законів було розроблено урядом для матеріальної підтримки і заохочення дорослих до освіти і навчання, зокрема «Закон про допомогу для освіти дорослих».

у країнах Європейського Союзу вже давно приділяється значна увага проблемі підготовки педагогів-андрагогів. Утвердилися прогресивні традиції у підготовці педагогічного персоналу для освіти дорослих. У більшості європейських університетів і вищих шкіл функціонують відділи, відділення освіти дорослих або факультети й кафедри андрагогіки (в університетах Великої Британії, Німеччини, Польщі, Сербії, Словенії, Чехії, Угорщини та ін.). Нині точиться дискусія щодо раціональних шляхів розвитку системи підготовки й удосконалення педагогічного персоналу для роботи з дорослими. Йдеться як про теоретикометодологічний, законодавчий, так і технологічний аспекти такої підготовки, спрямованої на формування і розвиток професійної компетентності андрагогів. Професійна підготовка андрагогів $\epsilon$ багаторівневою й різноспрямованою й здійснюється в університетах за програмами професійного навчання, післядипломної й додаткової освіти. у багатьох країнах андрагогічна підготовка фахівців здійснюється на рівнях бакалаврату, магістратури й підвищення кваліфікації.

Стан освіти дорослих у сучасній Україні

Українська держава помітно відстає у розвитку освіти дорослих. Це спричинено необґрунтованістю й низьким рівнем реалізації державної політики у сфері освіти дорослих, відсутністю необхідної законодавчої бази, зокрема Закону «Про освіту дорослих», а відповідно - й належного фінансування для навчання різних категорій дорослого населення. У державі не передбачено навіть офіційної статистики щодо освіти дорослих. В органах державної влади та управління освітою різних рівнів немає компетентного персоналу, відсутні відповідні структурні підрозділи, а в департаментах та управліннях освіти і науки обласних, міських і районних державних адміністрацій немає навіть жодного працівника, відповідального за цю сферу. Частково ці функції виконують науково-методичні і навчально-методичні центри професійно-технічної освіти в областях.

В Україні фактично існують форми освіти дорослих, які за структурними ознаками охоплюють три складові системи: формальна, неформальна, інформальна освіта. Особливого значення набуває неформальна освіта дорослих, «у містах, що навчаються» (глобальна мережа ЮНЕСКО міст, що навчаються). Ця сфера $є$ неоднорідною, розгалуженою, представлена різними суб'єктами, які, у свою чергу, мають свої цілі, а для їх досягнення використовують різні підходи. Здебільшого неформальна освіта не фінансується 3 державного бюджету й не завжди розглядається як складова сучасної освіти.

В Україні функціонують 17 міністерств і близько 70 комітетів і служб державної влади, у підпорядкуванні яких діють навчальні заклади й центри для підготовки, підвищення кваліфікації керівників і фахівців різного профілю. Їх фінансування здійснюється з державного бюджету й спрямовується на підвищення кваліфікації і перепідготовку дипломованих фахівців. Проте обсяги фінансування $\epsilon$ недостатніми для мінімального забезпечення системного навчання працівників різних галузей економіки.

Для забезпечення ефективної діяльності підприємства недостатньо укомплектувати персонал, сьогодні вкрай необхідно здійснювати цілеспрямовані інвестиції в людський капітал. Успішною та конкурентоспроможною визнається організація, здатна до системного корпоративного навчання. За прогнозами експертів, найближчим часом кількість корпоративних університетів суттєво перевищить чисельність академічних закладів вищої освіти й щорічно навчатиметься не менше 70\% найманих працівників (Hearn, 2001).

Відповідно до законодавства підприємства в Україні практично не мають зобов'язань щодо підготовки та підвищення кваліфікації виробничого персоналу й лише на мінімальному рівні здійснюють фінансування його професійного навчання. Ефективна внутрішньофірмова перепідготовка персоналу доступна лише великим компаніям. Витрати вітчизняних роботодавців на професійне 
навчання одного працюючого є досить низькими і в середньому становлять менше 1\% від фонду оплати праці. Тоді як досвід окремих конкурентоспроможних вітчизняних і багатьох зарубіжних підприємств свідчить, що витрати на професійне навчання персоналу мають становити понад 5\% фонду оплати праці (Савченко, 2004). Незначні витрати на професійне навчання персоналу на виробництві зумовлені відсутністю зацікавленості керівників організацій, а також скороченням чисельності працівників структурних підрозділів з організації професійного навчання.

Актуальним також $€$ здійснення заходів 3 розвитку цифрового суспільства; підвищення рівня комп'ютерної грамотності дорослого населення, зокрема пенсіонерів, малозабезпечених осіб та осіб, які потребують соціальної допомоги та реабілітації; створення умов для оволодіння ними комп'ютерною грамотністю. Розпорядженням Кабінету Міністрів України від 17 січня 2018 р. № 67-р. схвалено Концепцію розвитку цифрової економіки та суспільства України на 2018-2020 роки та затверджено план заходів щодо іï реалізації (Кабінет Міністрів України, 2018). В Україні відсутні програми, спрямовані на створення комплексної національної системи розвитку цифрової грамотності різних категорій дорослого населення. На думку експертів, «в умовах відсутності сформованої та виваженої політики з цього напряму сфера цифрових компетенцій в Україні розвивається хаотично та окремо від формальної освіти, що суттєво впливає як на якість формування людського капіталу, так і на можливість його реалізації» (Куйбіда, Петроє, Федулова \& Андрощук, 2019).

Об'єктивна потреба розвитку освіти людей третього віку в Україні зумовлена зростанням питомої ваги літніх людей та людей похилого віку, а відтак необхідністю наукового обгрунтування нової філософії старіння та забезпечення відповідних умов для «успішної старості» в життєвому циклі кожної людини. За прогнозами демографів, у переважній більшості країн Європи та в Україні загальна чисельність економічно активного населення у довгостроковій перспективі матиме тенденцію до скорочення (Лібанова, 2006).

Безумовно, системні заходи на загальнодержавному, регіональних та локальних рівнях вплинули на пробудження інтересу в усіх регіонах й поглиблення розуміння важливості освіти дорослих у педагогізації різних категорій населення. Нині карта України з освіти дорослих - це багата палітра інноваційних осередків різних типів, що діють у Києві, Миколаєві, Львові, Нікополі, Мелітополі, Полтаві й Кременчузі, Сумах, у Яворівському і Сколівському районах Львівської області та інші. Ця карта щороку доповнюється й збагачується новими адресами. Один із прикладів педагогічно-просвітницької діяльності серед різних категорій населення - старовинне гірське село Колочава на Закарпатті. Тут зусиллями місцевих краєзнавців створено десять музеїв, з 2006 р. видається історико-культурологічний літопис «Нова Колочава». Усе це свідчить про помітне зростання уваги громадських організацій та науковців до розвитку освіти дорослих.

Слід наголосити, що розвиток освіти дорослих у різних регіонах нашої держави має певні особливості й труднощі. Так, у Донецькій і Луганській областях цю проблематику підхопили не лише формальні й неформальні організації, завдяки яким здійснюється освіта дорослих, а й волонтерські та новоутворені осередки Товариства «Знання» України в містах Слов'янську, Покровську, Краматорську, Дружківці, Бахмуті, а також тимчасові культурно-просвітницькі творчі колективи, корпоративні університети тощо.

Наукове забезпечення розвитку освіти дорослих у діяльності Національної академії педагогічних наук України

Упродовж останніх 15 років Національна академія педагогічних наук України посилила увагу до наукового забезпечення розвитку освіти дорослих. Насамперед йдеться про аналітичні документи, підготовлені вченими академічних інститутів за редакцією В.Г. Кременя. Йдеться про «Білу книгу національної освіти України (2010), Національні доповіді «Про стан і перспективи розвитку освіти в Україні» (2011, 2016). Після опублікування цих аналітичних документів загальнодержавного і прогностичного значення Президією НАПН України, академічними відділеннями, й зокрема Відділенням професійної освіти і освіти дорослих, а також структурними підрозділами академії й особливо Інститутом педагогічної освіти і освіти дорослих імені Івана Зязюна НАПН України цілеспрямовано проводиться значна робота, спрямована на наукове забезпечення освіти дорослих.

Проблемі наукового забезпечення розвитку освіти дорослих присвячено нинішні загальні збори нашої академії. Наукове і методичне забезпечення освіти, зокрема освіти дорослих, передбачено Законом України «Про освіту». У ст. 18 
цього закону визначено, що «освіта дорослих $\epsilon$ складовою освіти впродовж життя, спрямована на реалізацію права кожної повнолітньої особи на безперервне навчання з урахуванням її особистих потреб, пріоритетів суспільного розвитку та потреб економіки». Наукового забезпечення потребують формальна, неформальна та інформальна освіта дорослих.

У ст. 75 цього закону обґрунтовано положення, що «наукове і методичне забезпечення освіти здійснюють центральний орган виконавчої влади у сфері освіти і науки, Національна академія наук України, національні галузеві академії України, органи із забезпечення якості освіти, центральні органи виконавчої влади, яким підпорядковані заклади освіти, академічні галузеві науководослідні інститути, заклади освіти, інші науковометодичні та методичні установи у взаємодії з відповідними підприємствами, творчими спілками, асоціаціями, товариствами, громадськими об'єднаннями, у тому числі фаховими організаціями (професійними асоціаціями, об'єднаннями роботодавців, незалежними установами оцінювання та забезпечення якості освіти)». Законом окреслено п'ять основних функцій щодо наукового і методичного забезпечення освіти. Це повною мірою стосується й освіти дорослих. Цією ж статтею окреслено дев'ять основних напрямів діяльності НАПН України щодо «розроблення і затвердження наукового і методичного забезпечення освіти для її окремих рівнів».

Нині посилюється актуальність методології андрагогічних наукових пошуків: обґрунтування дидактики освіти дорослих та інноваційних технологій їх навчання; розширення функцій освіти дорослих відповідно до концепції навчання впродовж усього життя; вдосконалення психолого-педагогічного супроводу навчання різних категорій дорослого населення; дидактичних комплексів для підготовки і професійного розвитку педагогічного персоналу для роботи з дорослими.

Вирішення цих та інших проблем пов'язано із науковим забезпечення розвитку освіти дорослих. Багато чого зроблено вперше. у 2008 р. в Україні вперше у науковій установі, зокрема в Інституті педагогічної освіти і освіти дорослих НАПН України, було створено відділ андрагогіки, який очолила проф. Л.Б. Лук'янова, а нині відділом керує проф. О.В. Аніщенко. Вчені цього Інституту стали ініціаторами і засновниками першої в Україні Громадської Спілки «Українська асоціація освіти дорослих» (2015р.), яка через рік (2016р.) стала членом Європейської асоціації освіти дорослих.

у листопаді 2014 р. під егідою Міністерства освіти і науки України, НАПН України та Національної комісії України у справах ЮНЕСКО відбувся Форум «Європейський Союз - Україна: освіта дорослих». У 2015 р. проведено Міжнародні дні освіти дорослих на Львівщині, а через рік - у Запорізькій області. У 2017 р. - перший Форум неформальної освіти дорослих «Освіта дорослих і розвиток громадянського суспільства».

Фундаментальні та прикладні дослідження у сфері освіти дорослих вперше розпочалися у 2008 р. в Інституті педагогічної освіти і освіти дорослих імені Івана Зязюна НАПН України (далі ІПООД). У табл. 1 наведено тематику і терміни виконання планових досліджень.

Табличя 1

Планові наукові дослідження з проблем освіти дорослих (2008-2019рр.)

\begin{tabular}{|c|c|c|}
\hline Назва теми & $\begin{array}{l}\text { Науковий } \\
\text { керівник }\end{array}$ & $\begin{array}{c}\text { Роки } \\
\text { виконання }\end{array}$ \\
\hline $\begin{array}{l}\text { «Теорія і практика } \\
\text { професійного } \\
\text { навчання дорослого } \\
\text { населення у ПТНЗ і } \\
\text { на виробництві» }\end{array}$ & $\begin{array}{c}\text { Лук'янова Л.Б., } \\
\text { д.п.н., } \\
\text { професор }\end{array}$ & 2008-2010 \\
\hline $\begin{array}{l}\text { «Теоретико- } \\
\text { методологічні і } \\
\text { методичні засади } \\
\text { освіти дорослих» }\end{array}$ & $\begin{array}{c}\text { Лук'янова Л.Б., } \\
\text { д.п.н., } \\
\text { професор }\end{array}$ & 2011-2013 \\
\hline $\begin{array}{l}\text { «Теорія і практика } \\
\text { особистісного і } \\
\text { професійного } \\
\text { розвитку дорослого } \\
\text { населення» }\end{array}$ & Аніщенко О.В., & 2014-2016 \\
\hline $\begin{array}{l}\text { «Теоретико- } \\
\text { методичні засади } \\
\text { розвитку освіти } \\
\text { різних категорій } \\
\text { дорослого } \\
\text { населення» }\end{array}$ & $\begin{array}{c}\text { Д.П.Н., } \\
\text { професор }\end{array}$ & 2017-2019 \\
\hline $\begin{array}{l}\text { «Технології навчання } \\
\text { дорослих в умовах } \\
\text { формальної і } \\
\text { неформальної } \\
\text { освіти» }\end{array}$ & $\begin{array}{c}\text { Вовк М.П., } \\
\text { д.п.н., пров.н.с. }\end{array}$ & 2017-2019 \\
\hline $\begin{array}{l}\text { «енденції розвитку } \\
\text { освіти дорослих у } \\
\text { розвинених країнах } \\
\text { світу» }\end{array}$ & $\begin{array}{c}\text { Авшенюк Н.М., } \\
\text { д.п.н., с.н.с. }\end{array}$ & 2017-2019 \\
\hline $\begin{array}{l}\text { «Психологічний } \\
\text { супровід навчання } \\
\text { різних категорій } \\
\text { дорослого } \\
\text { населення» }\end{array}$ & $\begin{array}{l}\text { Ігнатович О.М., } \\
\text { д.п.н., пров.н.с. }\end{array}$ & 2017-2019 \\
\hline
\end{tabular}

Джерело: Звіти Про діяльність ІПООД імені Івана Зязюна НАПН України за 2008-2019 рр. 
Узагальнення результатів цих досліджень уможливило висновок щодо їх інноваційності, зокрема:

- виявлено тенденції розвитку освіти дорослих в Україні та зарубіжних країнах з високим рівнем соціально-економічного розвитку;

- здійснено аналіз законодавчого забезпечення освіти дорослих у зарубіжних країнах;

- обґрунтовано концептуальні засади використання технологій навчання дорослих в умовах формальної і неформальної освіти;

- обґрунтовано моделі центрів освіти дорослих в умовах формальної і неформальної освіти;

- запропоновано новітні підходи і програми психологічного супроводу навчання дорослих 3 урахуванням криз вікового розвитку дорослої людини.

Про затребуваність результатів наукових досліджень свідчать результати їх завантажень 3 електронної бібліотеки НАПН України. Наприклад, за темою наукового дослідження «Теоретикометодичні засади розвитку освіти різних категорій дорослого населення» РК № $0117 \cup 001071$ в електронну бібліотеку НАПН України внесено 136 повно-текстових ресурсів, які знаходяться у вільному доступі. Станом на початок листопада 2020 р. зафіксовано понад 16 тис. завантажень (рис. 3).

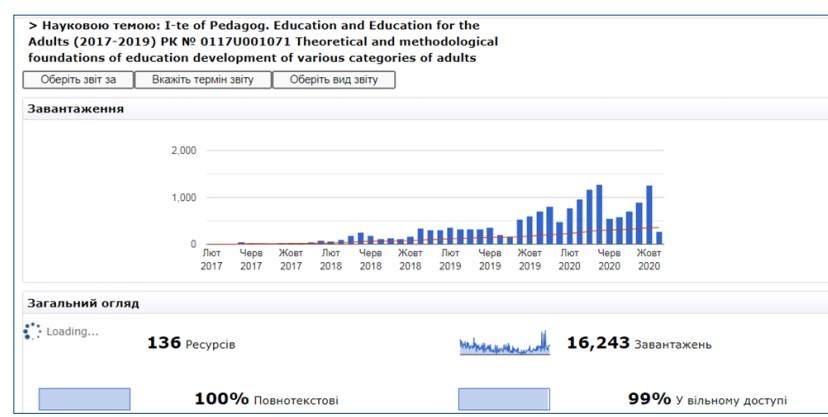

Рис. 3. Динаміка завантажень наукових праць за темою «Теоретико-методичні засади розвитку освіти різних категорій дорослого населення»

За результатами дослідження 3 теми «Тенденції розвитку освіти дорослих у розвинених країнах світу» PK № 0017U001070 в електронну бібліотеку НАПН України внесено 59 повнотекстових ресурсів, які знаходяться у вільному доступі. На початок листопада 2020 р. зафіксовано майже 10 тис. завантажень цих ресурсів (рис. 4).

За результатами завершених наукових досліджень підготовлено, опубліковано й експериментально перевірено ефективність наукового, науково-методичного забезпечення навчання різних категорій дорослих, зокрема: 39 монографій,

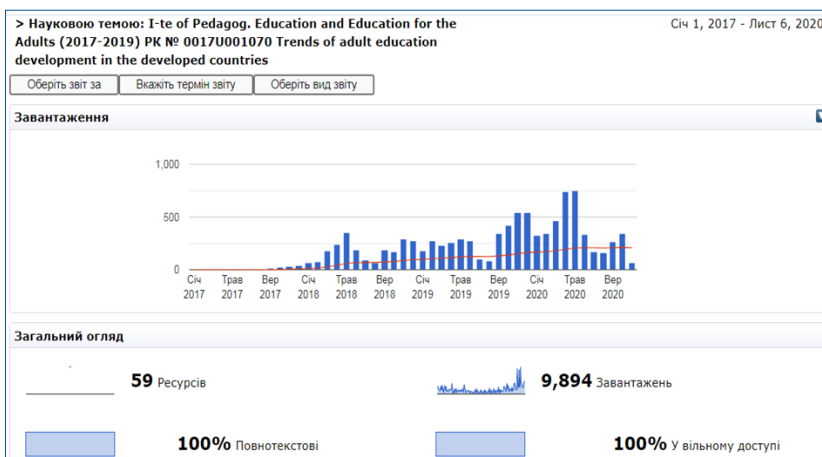

Рис. 4. Динаміка завантажень наукових праць за темою «Тенденції розвитку освіти дорослих у розвинених країнах світу»

28 посібників (навчальних, практичних, методичних), 20 методичних рекомендацій, 15 навчальних програм, 11 довідкових видань та 9 збірників наукових праць за матеріалами форумів, конференцій (рис. 5).

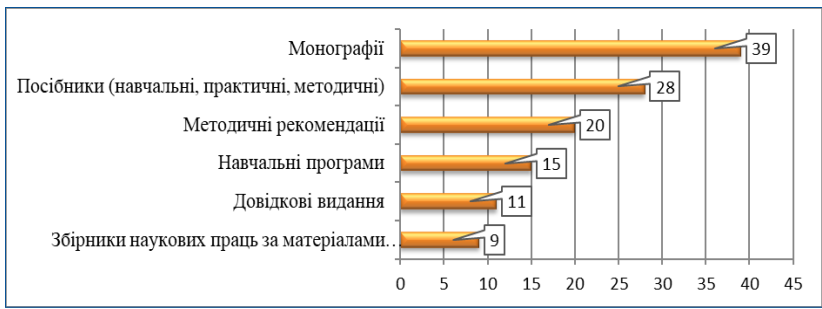

Рис. 5. Науково-видавнича діяльність з проблем освіти дорослих

Результати цих та інших досліджень використано для розроблення проєктів законодавчих і нормативно-правових та інших документів у сфері освіти дорослих, упроваджено в осередках формальної і неформальної освіти молоді й дорослих у різних регіонах України. Зокрема:

- Вченими ІПООД створено комплекс праць, зокрема «Концепція розвитку освіти дорослих в Україні» (Лук'янова, 2016), «Законодавче забезпечення освіти дорослих: зарубіжний досвід» (Лук'янова, 2016); «Концепція розвитку освіти і навчання дорослих в Україні» (Лук'янова, Аніщенко, \& Москаленко, 2019) стали підґрунтям для удосконалення проєкту Закону України «Про освіту дорослих», який пройшов громадське обговорення, а також проєктів законів України про внесення змін до Бюджетного та Податкового кодексів, щодо підтримки освіти дорослих (МОН України, 2020).

- Проєкт розробленої вченими цього академічного інституту кваліфікаційної характеристики професії (посади) «Андрагог» для педагогічних і науково-педагогічних працівників закладів формальної і неформальної освіти покладено в основу обґрунтованого Міністерством соціальної 
політики України проєкту «Зміни № 8 до Класифікатора професій» (2019), згідно з яким професію «Андрагог» (код КП - 2359.2, професійне угрупування «Інші професіонали в галузі навчання») внесено до Класифікатора професій (ДК 003:2010).

- Розроблено проєкти нормативно-правових документів та науково-методичні рекомендації щодо організаційного забезпечення діяльності центрів освіти дорослих (положення, інструктивні матеріали) для відкриття центрів освіти дорослих (при об'єднаних територіальних громадах, закладах вищої освіти тощо).

Розроблено й впроваджено:

- навчальні модулі з освіти дорослих для варіативних, різнорівневих програм підвищення кваліфікації та стажування педагогічного персоналу закладів формальної і неформальної освіти: «Формування андрагогічної компетентності наукових, науково-педагогічних і педагогічних працівників»; «|нноваційні технології навчання дорослих»; «Психологія взаємодії з людьми віку пізньої дорослості»;

- навчальну програму з професіоналізації освіти дорослих для тренерів і викладачів, які працюють з дорослими «Вступ до освіти дорослих» (ініціатива DVV International);

- методики авторських тренінгів для педагогічного персоналу у сфері формальної і неформальної освіти дорослих: тренінг для викладачів / тренерів, які працюють з дорослими «Як навчати дорослих: крокуємо до успіху» у рамках проєкту «Освітня програма підготовки професіоналів у галузі освіти дорослих включно з питаннями громадянської освіти»; цикл тренінгів «Як створити громадську організацію» та інші.

У різних регіонах України широко впроваджуються науково-методичні розробки, зокрема:

- 2 моделі: модель психолого-педагогічного супроводу навчання соціально-вікових категорій дорослого населення; модель педагогізації батьків і членів родин;

- 10 технологій, з них: 5 технологій навчання різних категорій дорослого населення в умовах формальної і неформальної освіти; 2 технології особистісного і професійного зростання у системі формальної і неформальної освіти; 3 технології психологічного супроводу навчання різних категорій дорослого населення;

- 2 навчальні програми з вивчення іноземної мови для закладів неформальної освіти;

- тренінги і науково-методичні рекомендації щодо організації і проведення семінарів-дискусій для педагогічного персоналу у сфері формальної і неформальної освіти дорослих тощо;

- психодіагностичні програми (виявлення освітніх потреб дорослого населення та особливостей педагогічної взаємодії з різними його категоріями; виявлення особистісно-професійного ресурсу; профдіагностики; оцінювання рівня усвідомлення стану психічного здоров'я і прагнення довголіття; спеціальні консультаційні та корекційні програми: профілактики регресивного особистісно-професійного розвитку; методи психогеронтологічної просвіти та навчання тощо).

Зростає значення інноваційних підходів, методик і механізмів розвитку освіти різних категорій населення, розроблених за результатами захищених кандидатських та докторських дисертацій з андрагогічних проблем. У 20102020 рр. у двох спеціалізованих вчених радах Інституту захищено 62 дисертації 3 проблем освіти дорослих, з них 32 докторських. У багатьох педагогічних університетах також посилено увагу до андрагогічних досліджень.

На підвищення якості й різновекторності наукового забезпечення ефективно впливає співпраця НАПН України, ІПООД з Міністерством освіти і науки України, Міністерством соціальної політики України та структурними підрозділами академії.

у науковому забезпеченні освіти дорослих набули розвитку нові напрями. Спільно з Українським науково-методичним центром практичної психології і соціальної роботи НАПН України створено Дистанційну школу демократії та громадянського суспільства з метою формування та розвитку громадянської компетентності різних категорій дорослих.

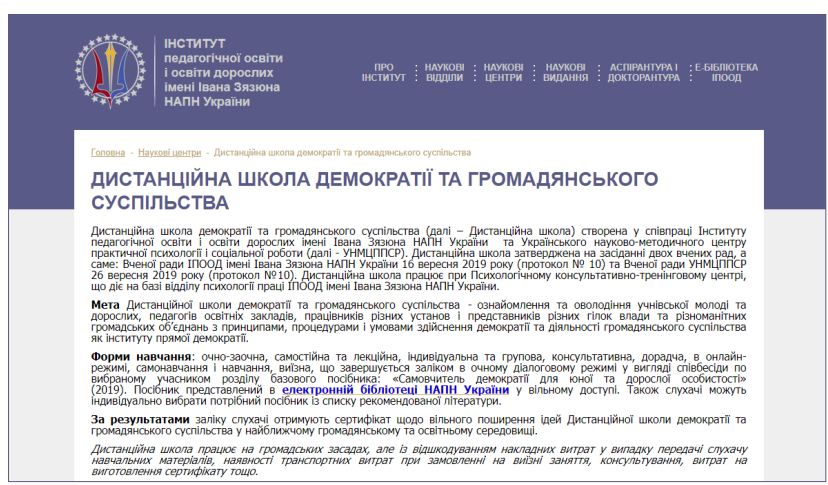

Упродовж п'яти років при Інституті психології імені Г.С. Костюка НАПН України на волонтерських засадах діє Кризовий центр медикопсихологічної допомоги, а при Інституті соціальної та політичної психології - Методичний реабі- 


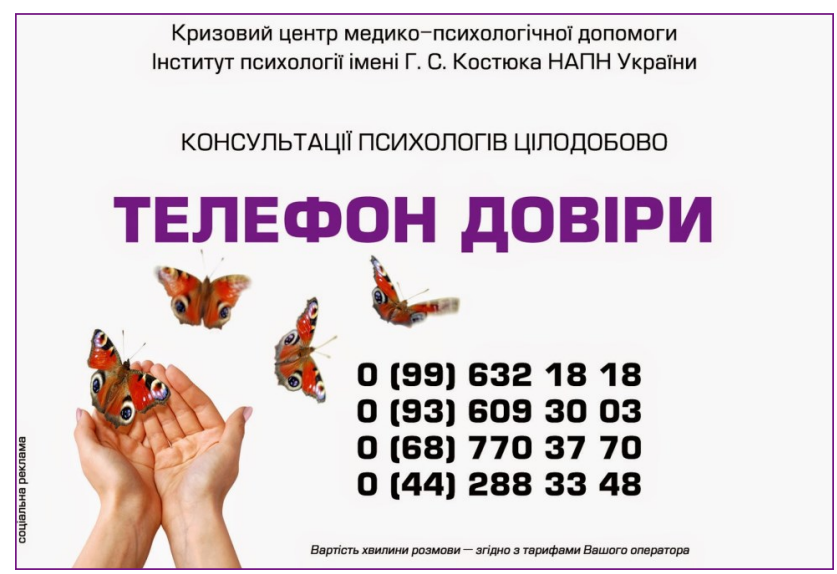

літаційний центр. Психологами здійснюється професійна підтримка фахівців, які працюють 3 постраждалими в зоні АТО / OОС, проводяться

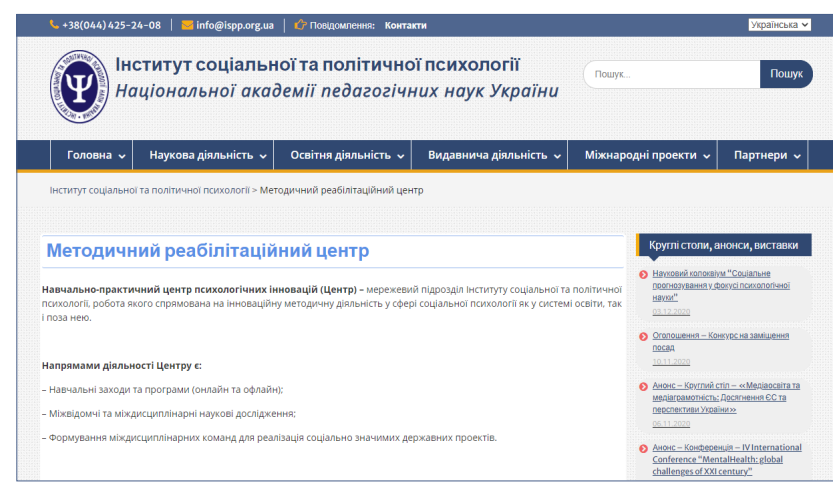

виїзні консультації для поранених, телефонне консультування, індивідуальна та групова робота з дітьми внутрішньо переміщених осіб, сім'ями загиблих тощо. Психологічну допомогу надано понад 2,1 тис. учасників бойових дій та членам їхніх сімей. У закладах професійної (професійнотехнічної) освіти Донецької і Луганської областей за участю Інституту професійно-технічної освіти НАПН України реалізується проєкт за програмою $\mathrm{OOH}$ із відновлення та розбудови миру.

Інноваційною $є$ співпраця ІПООД з шістьма віртуальними кафедрами Українського відкритого університету післядипломної освіти Державного закладу вищої освіти «Університет менеджменту

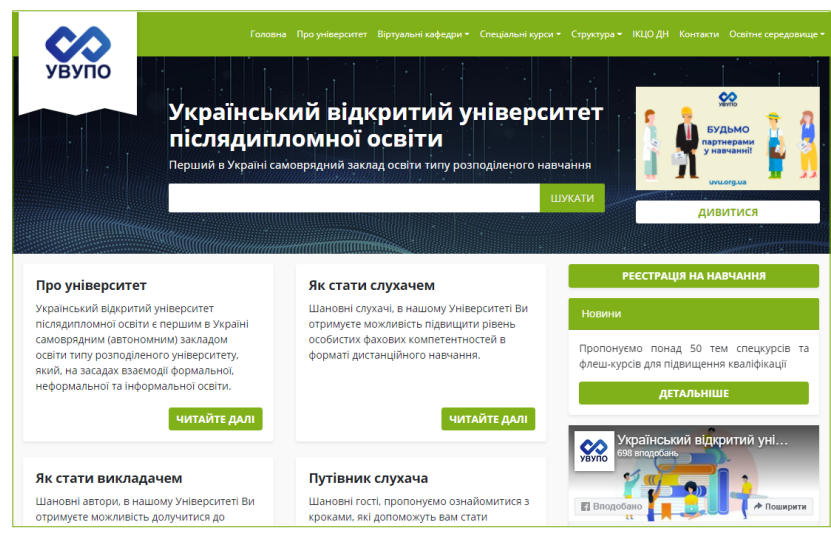

освіти» НАПН України. Віртуальна аудиторія цих кафедр у соціальних мережах охоплює понад 40 тис. користувачів. Спільно з Центральним інститутом підвищення кваліфікації розроблено комплекс навчальних матеріалів для дистанційного навчання: текстові матеріали, відео та аудіоматеріали, презентації, Internet-конференції, вебсемінари, тренінги тощо.

Особливого значення набуває розвиток медіа та інформаційної грамотності, що забезпечуватиме стійкість громадян до дезінформації, пов'язаної з можливими кризами в майбутньому. Підтримуючи Сеульську декларацію з медіа та інформаційної грамотності (прийняту Глобальним форумом у жовтні 2020 р.), слід наголосити, що розвиток освіти впродовж життя в цифровому мережевому суспільстві на всіх рівнях забезпечуватиме формування медіа та інформаційної грамотності, медіакультури і медіапсихологічної компетентності, зокрема в центрах професійного розвитку педагогів, центрах освіти дорослих, університетах третього віку тощо. Ідеї творчого доробку науковців Інституту соціальної та політичної психології НАПН України, зокрема Концепції впровадження медіаосвіти, мають важливе значення для наукового і методичного забезпечення розвитку освіти дорослих.

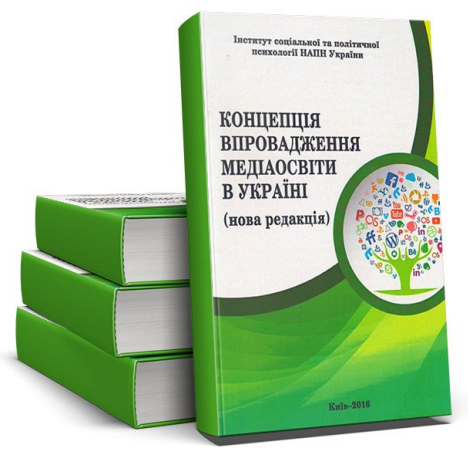

Вдосконаленню наукового забезпечення освіти дорослих сприяє діяльність кафедри ЮНЕСКО «Неперервна професійна освіта XXI століття», створеної за сприяння Президії НАПН України та Національної Комісії ЮНЕСКО в Україні. Завдяки взаємодії цієї Кафедри, громадських організацій та ІПООД розробляються варіативні, різнорівневі, диверсифіковані за профілем і терміном програми з підготовки та підвищення кваліфікації педагогічних та науково-педагогічних працівників, вивчається досвід зарубіжних країн 3 освіти дорослих, проводяться наукові консультації щодо розроблення й імплементації національ- 


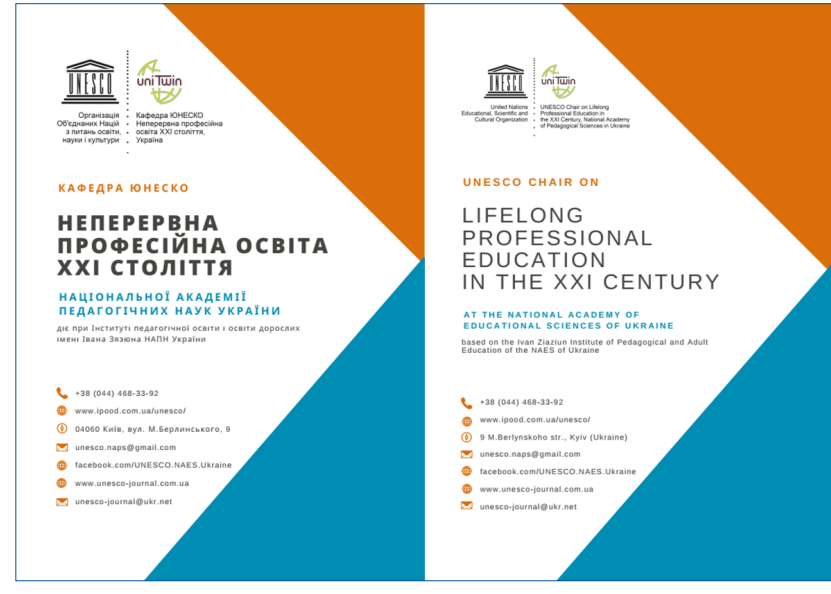

них стратегій неперервної професійної освіти дорослих засновано двомовний журнал «Вісник кафедри ЮНЕСКО НАПН України «Неперервна професійна освіта XXI століття».

Науковий доробок ІПООД та Кафедри ЮНЕСКО «Неперервна професійна освіта XXI століття» 2527 жовтня 2017 р. презентувався на Шостій міжнародній міжурядовій конференції ЮНЕСКО 3 питань освіти і навчання дорослих в м. Сувон, Республіка Південна Корея, Експертного Комітету Середньострокового огляду «Життя та навчання для життєздатного майбутнього: погляд у 2030 рік».

Важливе значення у формуванні позитивного іміджу ролі освіти дорослих у сучасному суспільстві відіграє проєктна діяльність вчених ІПООД. Так, у 2020 р. проєкт «Психологічна підтримка літніх осіб в умовах карантину» рекомендовано

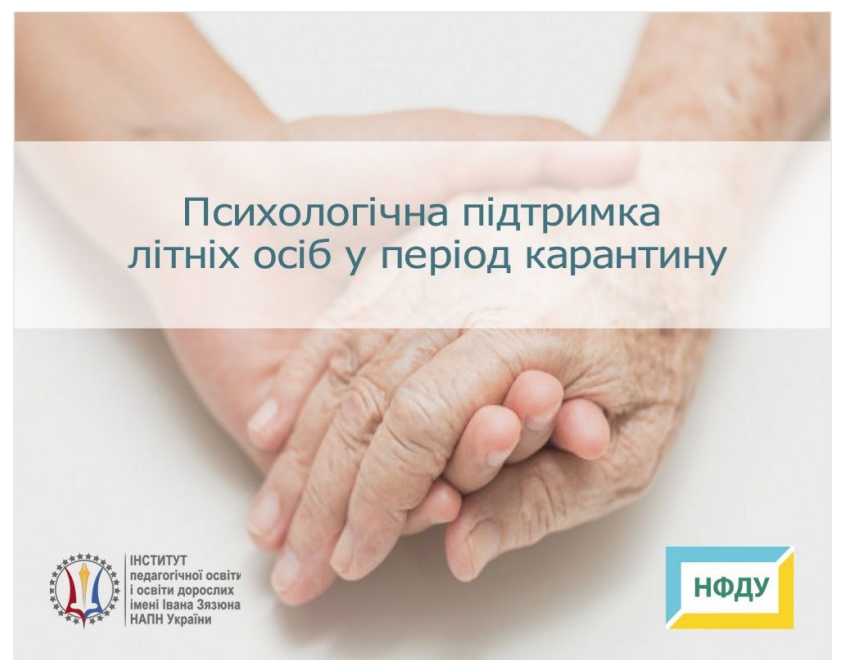

до реалізації за рахунок грантової підтримки Національного фонду досліджень України (протокол Наукової ради фонду від 16-17 вересня 2020 р. № 21) як переможець конкурсу «Наука для безпеки людини та суспільства». Загальна мета проєкту - сприяння розвитку особистості літнього віку, яка перебуває у складних життєвих обставинах, пов'язаних 3 карантинними обмеженнями.

Результативною й перспективною у вдосконаленні наукового забезпечення освіти дорослих $\epsilon$ співпраця НАПН України з Представництвом Інституту з міжнародного співробітництва Німецької асоціації народних університетів DVV International в Україні, що здійснюється відповідно до Угоди від 5 листопада 2014 р.

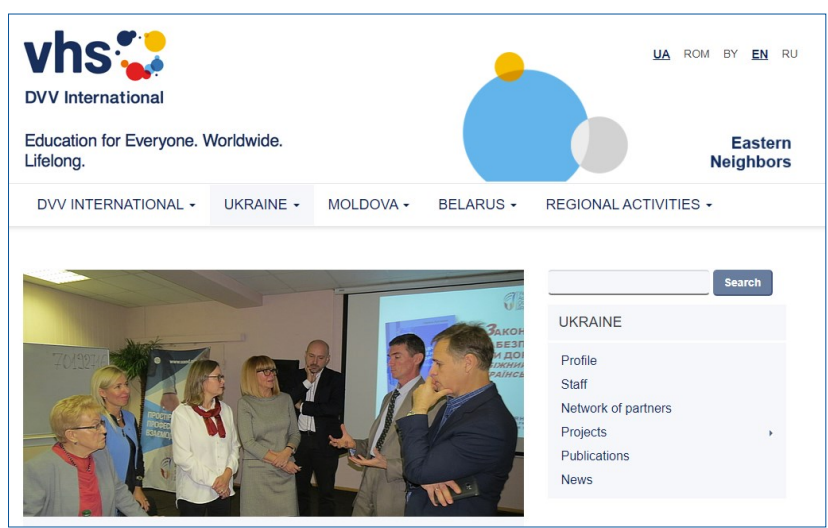

Основні результати цієї співпраці:

- проведення досліджень (2015-2020рр.) 3 вивчення освітніх потреб населення окремих регіонів України з урахуванням їхньої соціальнодемографічної структури;

- виявлення рівня затребуваності освітніх послуг, оцінювання їх якості та визначення перспективних напрямів розвитку освітнього простору у Запорізькій, Дніпропетровській областях та м. Києві;

- участь в освітніх програмах «Професіоналізація освіти дорослих включно з питаннями громадянської освіти» (180 годин), «Підготовка фахівців у сфері освіти для дорослих, включно 3 питаннями громадянської освіти» (156 годин);

- розроблення та впровадження авторських і корпоративних тренінгових програм для різних категорій дорослих.

Президія НАПН України неодноразово розглядала питання освіти дорослих, зокрема:

- у 2010 р. і 2016 р. обговорено і схвалено Концепцію розвитку освіти дорослих в Україні (Лук'янова, 2016),

- у 2016 р. - «Про діяльність Інституту педагогічної освіти і освіти дорослих НАПН України 3 реалізації Концепції розвитку освіти дорослих в Україні»;

- у 2017 р. - «Про виконання Угоди щодо спільної діяльності Національної академії педагогічних наук України, Товариства «Знання» України 
та Представництва німецької неурядової організації «німецьке об'єднання народних університетів» DVV International в Україні.

Проєкти концепцій розвитку освіти дорослих в Україні (2011, 2016 рр.), проміжні і кінцеві результати наукових досліджень обговорювалися на засіданнях Відділення професійної освіти і освіти дорослих та його бюро. Відділення виконує консультативно-координаційну функцію, спрямовує свою діяльність на забезпечення й утвердження нових напрямів у роботі з різними категоріями дорослого населення. Члени Відділення брали участь у засіданнях круглих столів, семінарів, конференцій, організованих спільно з Міністерством освіти і науки України, представництвом німецької неурядової організації «Німецьке об'єднання народних університетів» DVV International в Україні і Товариством «Знання» України та Українською асоціацією освіти дорослих.

Актуальні проблеми в розвитку освіти дорослих та науково обґрунтовані пропозиції щодо їх розв'язання

Узагальнивши результати аналізу стану наукового забезпечення освіти дорослих, вважаємо за доцільне привернути увагу до невикористаних резервів, що гальмують розвиток освіти дорослих в Україні.

- Фрагментарною є співпраця НАПН України та ії структурних підрозділів з іншими профільними міністерствами, зокрема Міністерством соціальної політики, Міністерством розвитку громад та територій, Міністерством культури, Міністерством юстиції України, зокрема з Державною кримінально-виконавчою службою України та ін. відомствами, а також територіальними громадами з питань освіти впродовж життя, які можуть бути потенційними замовниками конкретних складових наукового забезпечення.

- Відділенням професійної освіти та освіти дорослих НАПН України, ІПООД ще не приділяється належної уваги вивченню освітніх потреб різних категорій дорослого населення, а також створенню освітніх програм для різних груп населення, зокрема й безробітних, осіб із обмеженими можливостями, осіб третього віку та інших громадян, позбавлених можливостей активної участі у соціальному, економічному й культурному житті суспільства, а також науковому супроводу неформальної освіти внутрішньо переміщених осіб, воїнів, військовослужбовців, які постраждали у ході бойових дій і в операціях з підтримання миру й безпеки.
- Академічні інститути не приділяють належної уваги вивченню досвіду волонтерства та соціального підприємництва у сфері освіти дорослих.

- Вченими недооцінюється значення відродження просвітницької діяльності, спрямованої на підвищення загальної і педагогічної культури та соціальної активності різних категорій дорослого населення.

У зв'язку із цим постає низка нових завдань, розв'язання яких потребує політичної волі, системної співпраці різних соціальних інститутів й гармонізації діяльності усіх гілок влади, об'єднаних територіальних громад і громадських організацій

Перше: Відділенню професійної освіти і освіти дорослих НАПН України, ІПООД необхідно продовжити методологічне обґрунтування державної політики, спрямованої на розвиток системи освіти дорослих в Україні та підготовку відповідних пропозицій. Йдеться не лише про майбутній Закон України «Про освіту дорослих», який, сподіваємося, незабаром буде прийнято Верховною Радою. Водночас зазначимо, що тільки цього закону недостатньо. Доцільно також переглянути інші закони, якими регулюються різні аспекти освіти дорослих, підвищення кваліфікації, перекваліфікації людини в умовах динамічних змін на ринку праці. Необхідно розробляти сучасні підзаконні акти, які $б$ регулювали діяльність різних міністерств і відомств, об'єднаних територіальних громад та громадських організацій. На національному рівні актуальними залишаються питання розроблення критеріїв визначення освітніх потреб, планування, контролю, звітності, а також вивчення міжнародного з питання створення системи добору статистичної інформації щодо освіти дорослих на місцевому, регіональному й національному рівнях.

Друге: об'єктивною стає потреба забезпечення психолого-педагогічної підготовки державних службовців у контексті виконання законодавства щодо освіти дорослих. У зв'язку з цим наголосимо на особливому значенні Концепції реформування системи професійного навчання державних службовців, голів місцевих держадміністрацій, їх перших заступників та заступників, посадових осіб місцевого самоврядування та депутатів місцевих рад, схваленої розпорядженням Кабінету Міністрів України 1 грудня 2017 р. Цією Концепцією передбачено формування цілісної, відкритої, гнучкої національної системи освіти дорослих, що 
охоплює формальну, неформальну та інформальну складові й спрямовується на задоволення освітніх потреб особистості.

Tpemє: подальший розвиток фундаментальних і прикладних досліджень з андрагогічних проблем. 3 метою здійснення міждисциплінарних досліджень Відділенню професійної освіти і освіти дорослих НАПН України, ІПООД та іншим академічним інститутам необхідно об'єднувати зусилля з вченими інститутів НАН України (Інститут демографії та соціальних досліджень імені М.В. Птухи, Інститут економіки та прогнозування тощо) та кафедрами педагогіки, психології, філософії, соціології вищих закладів освіти. Постає питання щодо створення банку даних з цієї проблеми, а також щодо впровадження результатів наукових досліджень у практику; розширення співпраці академічних інститутів з національними університетами та відповідними міністерствами і відомствами

Четверте: Відділенню професійної освіти і освіти дорослих НАПН України, ІПООД, кафедрі ЮНЕСКО доцільно виявляти і творчо впроваджувати прогресивні і конструктивні ідеї зарубіжного досвіду. Необхідно розширювати напрями співпраці з Представництвом німецької неурядової організації «Німецьке об'єднання народних університетів» DVV International в Україні та іншими міжнародними організаціями; здійснення експертизи результатів завершених проектів та їх оприлюднення

П'яте: розвиток освіти дорослих в нашій державі, безсумнівно, сприятиме педагогізації українського суспільства. Йдеться про педагогізацію освітнього простору як села, так і міста. У сучасних умовах доцільно підтримувати ініціативи щодо використання різних форм організації освіти дорослих для поширення психологопедагогічних знань, підготовки до батьківства, ознайомлення слухачів університетів третього віку, центрів освіти дорослих та інших осередків з проблемами педагогіки родини, педагогіки культури, музейної педагогіки тощо. Важливого значення набуває системне поширення психолого-педагогічних знань серед різних категорій дорослого населення у регіонах з урахуванням їхньої соціально-демографічної структури. Посилення уваги вчених потребує обгрунтування інноваційних моделей розвитку освіти дорослих з урахуванням соціально-економічних й етнонаціональних особливостей й освітніх потреб різних категорій дорослого населення кожного регіону.
Здійснений аналіз дає змогу обґрунтувати засади системної організації простору освіти дорослих. Він має базуватися на єдності формальної, неформальної та інформальної освіти й мати тривимірну структуру (рівневу, орієнтаційну, галузеву). Відповідно до тривимірної структури доцільно запровадити базову кодифікацію освітніх програм (курсів) та отриманих кваліфікацій (компетентностей) й передбачати кредитну кодифікацію. Необхідно створити систему забезпечення якості освіти дорослих, що передбачає програмну та інституційну акредитацію, а також Єдиний електронний реєстр усіх кодифікованих, кредитованих та акредитованих освітніх програм (курсів) та відповідних кваліфікацій (компетентностей). Для моніторингу стану і розвитку освіти дорослих слід запровадити систему збирання й адміністрування статистичних даних, доступних онлайн.

На законодавчому рівні варто мотивувати роботодавців до реалізації освіти дорослих шляхом ії фінансування (як частки фонду оплати праці).

До перспективних напрямів вдосконалення наукового забезпечення освіти дорослих доцільно віднести:

- наукове обґрунтування Національної системи кваліфікацій;

- посилення міжнародної проєктної і науково-видавничої діяльності;

- розроблення та впровадження для різних верств населення програм «цифрового лікбезу» 3 метою упередження цифрової нерівності громадян країни;

- розвиток взаємодії з Центрами професійного розвитку педагогів у регіонах з метою здійснення наукового супроводу формальної і неформальної освіти педагогічного персоналу;

- створення на базі ІПООД центру музейної педагогіки з метою поширення міждисциплінарних знань з проблем збереження культурної спадщини, використання потенціалу неформальної освіти та розвитку педагогічно-просвітницької діяльності;

- створення інноваційного банку ідей 3 розвитку освіти дорослих;

- здійснення тренінгової діяльності у закладах освіти дорослих в умовах пандемії, проведення онлайн заходів для педагогічного персоналу 3 метою упровадження інноваційних педагогічних ідей у закладах формальної і неформальної освіти. 
Отже, подальший розвиток освіти дорослих в Україні закономірно пов'язаний 3 державною стратегією, послідовною реалізацією державної політики у сфері освіти дорослих, створенням необхідних соціально-економічних умов для діяльності різних громадських формувань, центрів освіти дорослих, університетів третього віку тощо. Усе це потребує інноваційних підходів до наукового забезпечення розвитку освіти дорослих в Україні.

\section{СПИСОК ВИКОРИСТАНИХ ДЖЕРЕЛ}

Закон України «Про освіту». (2017, 5 вересня). https:// zakon.rada.gov.ua/laws/show/2145-19

Кабінет Міністрів України. (2017, 12 грудня). Про схвалення Концепиії реформування системи професійного навчання державних службовців, голів місцевих державних адміністрацій, їх перших заступників та заступників, посадових осіб місцевого самоврядування та депутатів місцевих pad (974-p). https://zakon.rada.gov.ua/laws/show/9742017

Кабінет Міністрів України. (2018, 17 січня). Концепиія розвитку цифрової економіки та суспільства України на 2018-2020 роки (67-p). https:// zakon.rada.gov.ua/laws/show/67-2018

Кремень, В.Г. (ред.). (2010). Біла книга національної освіти України. Київ: АПН України. http:// www.ukraine3000.org.ua/img/forall/APN.pdf

Кремень, В.Г. (ред.). (2011). Національна доповідь про стан і перспективи розвитку освіти в Україні. Національна академія педагогічних наук України. Київ: Педагогічна думка. https://bit.ly/2Vvrh0n

Кремень, В.Г. (ред.). (2016). Національна доповідь про стан і перспективи розвитку освіти в Україні. Національна академія педагогічних наук України. Київ: Педагогічна думка. https://lib.iitta.gov.ua/166230/

Куйбіда, В.С., Петроє, О.М., Федулова, Л.І., \& Андрощук, Г.О. (2019). Цифрові компетенції як умова формування якості людського капіталу : аналітична записка. Збірник наукових праць Національної академії державного управління при Президентові України, (1), 118-133. https://doi.org/10.36030/26643618-2019-1-118-133

Лібанова, Е.М. (ред.). (2006). Комплексний демографрічний прогноз України на період до 2050 р. : монографія. Київ: Український центр соціальних реформ. http://database.ukrcensus.gov.ua/PXWEB2007/ukr/ analis/index.asp

Луговий, В.І., \& Таланова, Ж.В. (2018). Засади системної організації простору освіти дорослих. In В.Г. Кремень, Н.Г. Ничкало, ред. Концептуальні засади розвитку освіти дорослих: світовий досвід, українські реалії і перспективи : збірник наукових статей (с. 12-21). Київ: Знання України. https://lib.iitta.gov.ua/712504/

Лук'янова, Л.Б. (2011). Концепція розвитку освіти дорослих в Україні. Ніжин: ПП Лисенко М.М.
Лук'янова, Л.Б. (2016). Концепція розвитку освіти дорослих в Україні. https://lib.iitta.gov.ua/7529/

Лук'янова, Л.Б. (2017). Законодавче забезпечення освіти дорослих: зарубіжний досвід. Видавництво ТОВ «ДКС-Центр». https://bit.ly/3fiQHНС

Лук'янова, Л.Б. (2018). Сучасні тенденції підготовки педагогічного персоналу для роботи з дорослими в європейських країнах. Андрагогічний вісник, (10), 7-17.

Лук'янова, Л.Б., Аніщенко, О.В., \& Москаленко, Л.М. (2019). Концепція розвитку освіти і навчання дорослих в Україні (проєкт). Громадська спілка «Українська асоціація освіти дорослих». https:// bit.ly/2I5NLIz

Міністерство економічного розвитку і торгівлі України. (2017). Національна доповідь "Цілі сталого розвитку: Україна». https://bit.ly/3qhXhmS

Міністерство економічного розвитку та торгівлі. (2019. 15 лютого). Про затвердження Зміни № 8 до національного класифікатора України ДК 003:2010. (259). https://www.msp.gov.ua/documents/4692.html

Міністерство освіти і науки України. (2020, 7 вересня). МоH пропонує для громадського обговорення проєкт Закону України «Про освіту дорослих». https://bit.ly/3lWykec

Найдьонова, Л.А., \& Слюсаревський, М.М. (ред.). (2016). Концепція впровадження медіаосвіти в Україні (нова редакція). http://mediaosvita.org.ua/ book/kontseptsiya-vprovadzhennya-mediaosvity/

Савченко, В. (2004). Визначення перспективних напрямів та обсягів професійного навчання безробітних відповідно до потреб ринку праці. Україна: аспекmи прачі, (5), 12-18.

Hearn, D.R. (2001). Education in the Workplace: An Examination of Corporate University Models. https:// www.newfoundations.com/OrgTheory/Hearn721.html

OECD. (2019). Getting Skills Right: Future-Ready Adult Learning Systems. Paris: OECD Publishing. https:// doi.org/10.1787/9789264311756-en

OECD. (2020). Education at a Glance. OECD Indicators. Paris: OECD Publishing. https://doi.org/10.1787/69096873-en

UNESCO, UNICEF, the World Bank, UNFPA, UNDP, UN Women, \& UNHCR. (2015). EDUCATION 2030. Incheon Declaration. Towards inclusive and equitable quality education and lifelong learning for all. http:// www.unesco.org/new/fileadmin/MULTIMEDIA/HO/ ED/ED_new/pdf/FFA-ENG-270ct15.pdf

UNESCO. (2010). CONFINTEA VI, Belém Framework for Action: harnessing the power and potential of adult learning and education for a viable future. UNESCO Institute for Lifelong Learning. https:// unesdoc.unesco.org/ark:/48223/pf0000187789

UNESCO. (2016). Recommendation on Adult Learning and Education, 2015. UNESCO Institute for Lifelong Learning. https://unesdoc.unesco.org/ark:/48223/pf0000245179 UNESCO. (2019). 4th Global Report on Adult Learning and Education: leave no one behind: participation, equity and inclusion. UNESCO Institute for Lifelong Learning. https://uil.unesco.org/adult-education/global-report/ fourth-global-report-adult-learning-and-education 


\section{SCIENTIFIC SUPPORT OF ADULT EDUCATION DEVELOPMENT IN UKRAINE}

Scientific report at the General Meeting of the National Academy of Educational Sciences of Ukraine, November 20, 2020

\section{Nellia Nychkalo}

DSc in Pedagogy, Professor, Full Member (Academician) of NAES of Ukraine, Academician Secretary of the Division of Professional and Adult Education, National Academy of Educational Sciences of Ukraine, Kyiv, Ukraine

Abstract. The problems of scientific support of adult education development in the context of globalization, European integration and transition to a digital society are revealed. The comparative analysis of foreign and Ukrainian experience in state educational policy implementation is fulfilled. Particular attention is paid to scientific support of adult education development in the National Academy of Educational Sciences of Ukraine activities. Attention is drawn to the valuable experience of educational activity for different categories of adult population in different regions of Ukraine, psychological rehabilitation of victims in the antiterrorist operation area in the Donetsk and Lugansk regions. The suggestions about further innovative researches in continuous education - lifelong learning are grounded.

Keywords: adult education; formal, informal and nonformal adult education; scientific support; andragogical educator; pedagogization. 